Int. J. Dev. Biol. 48: 1079-1085 (2004)

doi: $10.1387 / \mathrm{ijdb} .041912$ ts

Original Article

\title{
The germ line lineage in ukigori, Gymnogobius species (Teleostei: Gobiidae) during embryonic development
}

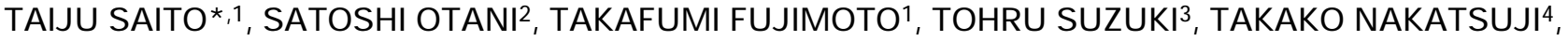 \\ KATSUTOSHI ARAI ${ }^{1}$ and ETSURO YAMAHA ${ }^{5}$
}

\begin{abstract}
${ }^{1}$ Laboratory of Breeding Science, Graduate School of Fisheries Science, Hokkaido University, ${ }^{2}$ Laboratory of Aquatic Biology, Faculty of Agriculture, Kinki University, ${ }^{3}$ Laboratory of Bioindustrial Informatics, Graduate School of Agriculture Science, Tohoku University, ${ }^{4}$ Department of Marine Biology, Graduate School of Marine Science and Technology, Tokai University and ${ }^{5}$ Nanae Fresh-Water Laboratory, Field Science Center for Northern Biosphere, Hokkaido University, J apan.
\end{abstract}

\begin{abstract}
In order to determine the origin and migration of ukigori primordial germ cells (PGCs), we observed the aggregation of vasa mRNA by whole mount in situ hybridization. To observe PGC migration in the germ layers, we analyzed HE-stained paraffin sections. The germ line lineages were derived from the edge of the first, second and third cleavage furrows. During subsequent cleavages, vasa mRNA aggregations were respectively taken into four to eight cells in each embryo and vasa expressing cells proliferated from the sphere stage. At the bud to early somitogenesis period, PGCs aligned from head to tail bud regions on both sides of the embryonic body. During the late somitogenesis period, PGCs mainly aggregated just underneath the body axis. After gut formation, PGCs aligned along both sides of the gut at the 4th- to 8th- somite regions. Finally, PGCs reached the genital ridge via the inside of the lateral plate mesoderm and dorsal peritoneum. These results suggest that localized patterns of vasa transcripts and the migration routes of PGCs are different among fish (Teleost) species, perhaps depending on the amount of germinal cytoplasm derived maternally and the timing of endoderm differentiation.
\end{abstract}

KEY WORDS: primordial germ cell, PGC, vasa, cell lineage, ukigori

\section{Introduction}

All sexually reproducing organisms arise from gametes. In turn, all gametes arise from primordial germ cells (PGCs), a small population of cells set aside from other cell lineages early in development. In many animals, PGCs have to migrate from the position where they are specified toward the genital ridge during the embryonic development (Reviewed by Wiley, 1999). During migration, PGC properties continuously change, although they essentially maintain developmental totipotency. These characteristics of PGCs make them an attractive system for studying cell fate specification, differentiation and migration (Reviewed by Raz, 2002). In addition, it is possible that PGCs could serve as tools for advanced technologies and reproductive biology, including genetic modification, cryopreservation and surrogate propagation (Reviewed by Yoshizaki et al., 2004; Saito and Yamaha., 2004).

Studies of Drosophila and Xenopus laevis PGCs revealed that they were specified by maternally provided cytoplasmic determinants (the germ plasm) that were partially localized in the eggs
(Reviewed by Wiley, 1999). The germ plasm is characterized by polar granules and an electron dense structure and contains the mitochondria, mRNA and proteins. In those components, in particular, vasa revealed the origin and migration of PGCs as molecular makers in many species, including chick (Tsunekawa et al., 2000) and zebrafish (Yoon et al., 1997). vasa is an ATP. dependent RNA helicase belonging to the DEAD-box family (Hay et al., 1988; Lasko and Ashburner, 1988). It was originally identified in Drosophila as a maternal effector gene required for abdominal segmentation and germ cell specification (Schüpbach and Wieshaus, 1986). In zebrafish, whole mount in situhybridization using vasa during embryonic development revealed that the germ cell lineage is determined by maternally provided factors and separates from somatic cells early in development, as in Drosophila and Xenopus (reviewed by Howard, 1998; Rongo et al., 1997; Wylie, 1999). In detail, vasa mRNA aggregates at both edges of the cleavage furrow(s) at the 2- to 4-cell stage. Occa-

Abbreviations used in this paper: HE, Hematoxylin \& Eosin; PGC, primordial germ cell; WISH, whole mount in situ hybridization; YSL, yolk syncytial layer.

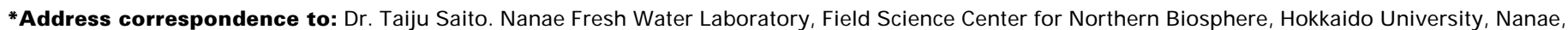
041-1105, J apan. Fax: +81-138-65-2239. e-mail: taiju@fish.hokudai.ac.jp
} 
sionally, vasamRNA localize at the edge of the third cleavage furrows, but this aggregation is degraded after the blastula stage. The PGCs proliferate after the blastula period and cluster around the first somites at the early segmentation period. Finally, clusters of PGCs migrate posterior to the junction of the yolk ball and yolk extension, the prospective genital ridge, keeping two clusters at both sides of the embryonic body (Yoon et al., 1997; Weidinger et al., 1999).

PGC migration during embryonic development has also been investigated in several fishes using vasa gene homologs. In goldfish, vasa transcripts are localized at both edges of the third cleavage furrows in addition to the first and second cleavage furrows (Otani et al., 2002). Moreover, it has been shown that the cells taking vasa transcripts from the third cleavage furrows proliferate after the blastula stage, unlike zebrafish. At the early segmentation period, PGCs align from head to tail on both sides of the body axis. Thereafter, the PGCs aggregate to the yolk extension (prospective genital ridge region) and form the two clusters on both sides of the body axis. On the other hand, in medaka, vasa positive cells were not detected until the late gastrula period (Shinomiya et al., 2000; Tanaka et al., 2001). vasa positive cells were apparent at the dorsal marginal region randomly at the $70 \%$ epiboly stage. At the early segmentation period, PGCs form two clusters beside the somites. Thereafter, PGCs migrate to the gut, remaining in two clusters. These results suggest that the determination mechanisms of PGCs vary between fish species, although it is necessary that additional PGC specific molecular markers, such as nanos homologue gene mRNA (Kobayashi et al., 1996; Köprunner et al., 2001), should be examined in medaka. However, the PGC migration patterns in these fishes correspond to the following points: 1) PGC origins are not related to the region of genital ridge formation, 2) PGCs localize on both sides of the body axis at the early segmentation period and 3) PGCs aggregate at the prospective genital ridge region while remaining in two clusters. The migration routes of PGCs, especially during the stages from the mesendodermal region to the genital ridge, have also been investigated histologically in several fishes. PGCs in medaka appear around the lateral endoderm at somitogenesis and move passively to the genital ridge via the outer layer of the lateral plate mesoderm at the side of gut (Gamo, 1961; Hamaguchi 1982). However, in other fishes, e.g. Fundulus heterclitus and black bass (Micropterus salmonides salmonides), PGCs migrate to the genital ridge via the inner layer of the lateral plate mesoderm (Richards and Thompson, 1921; Johnston, 1951). On the other hand, in zebrafish, during the course to genital ridge, PGCs form the pseudopodium, suggesting active movement (Braat et al., 1999). Results of these studies suggest that the final step of the PGC migration mechanism to the genital ridge varies between fish species. The origin and migration of PGCs in teleost fishes has not been explained by common concepts, as mentioned above. This might be caused by the remarkable diversity of teleost fishes. For comprehensive understanding of teleost PGCs, genetic analysis such as large-scale mutant screening as in zebrafish is one strategy, another workable strategy is comparison between model fishes and other fish species. However, studies of PGCs using molecular markers are restricted to a few fishes, namely, zebrafish, goldfish and medaka.
In Perciformes, the most evolved group of teleost fish, the origin and migration of PGCs have not been investigated in detail. In this study, we investigate these aspects of PGCs in ukigori, Chaenogobius species (Family Gobiidae), by whole mount in situ hybridization and histological observation in $\mathrm{HE}$ stained paraffin sections.

\section{Results}

\section{vasa RNA expression in the early embryo}

To reveal the origin of $P G C s$, localization of vasatranscripts was investigated from the 2-cell stage to 5 day post-fertilization (dpf) by WISH, using shiro-uo vasa probes. We did not observe localization of vasa transcripts in unfertilized eggs or 1-cell stage embryos, on account of difficulties in sampling and fixing embryos of those stages. At the 2-cell and 4-cell stage, vasa transcripts were enriched at the marginal positions of the first (Fig. $1 \mathrm{~A}, \mathrm{~B}$ ) and the second cleavage plane (Fig. 1 C,D). At the third cleavage plane, new vasa transcripts accumulation(s) were observed in some embryos. In the case that the third cleavage furrows divide horizontally, vasamRNA was enriched between the upper and lower tiers of the blastomeres at the 8cell stage (Fig. $1 \mathrm{E}, \mathrm{F}$ ). At the 16 -cell stage, 4 to 8 signals of vasa mRNA were observed in the cleavage planes of each embryo (Table 1). At the 512-cell stage, the number of vasa dots was 4 to 7 in each embryo (Table 1). Accumulations of vasa tran-
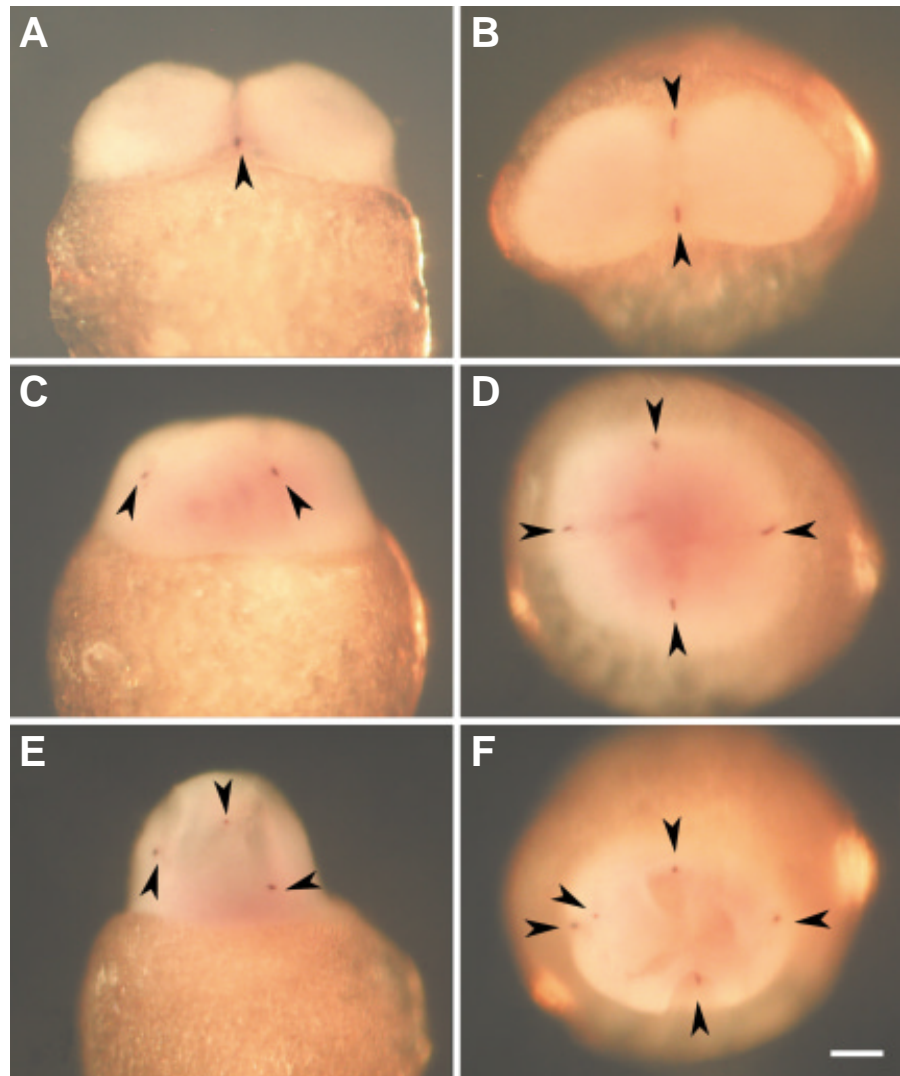

Fig. 1. Distribution of vasa-positive dots from the 2-cell to 8-cell stage. (A,B) 2-cell, (C,D) 4-cell and (E,F) 8-cell stage embryos. (A, C, E) are lateral views, while $(B, D, F)$ are animal pole views. Arrowheads indicate the accumulation of vasa transcripts. The scale bar indicates $50 \mu \mathrm{m}$. 

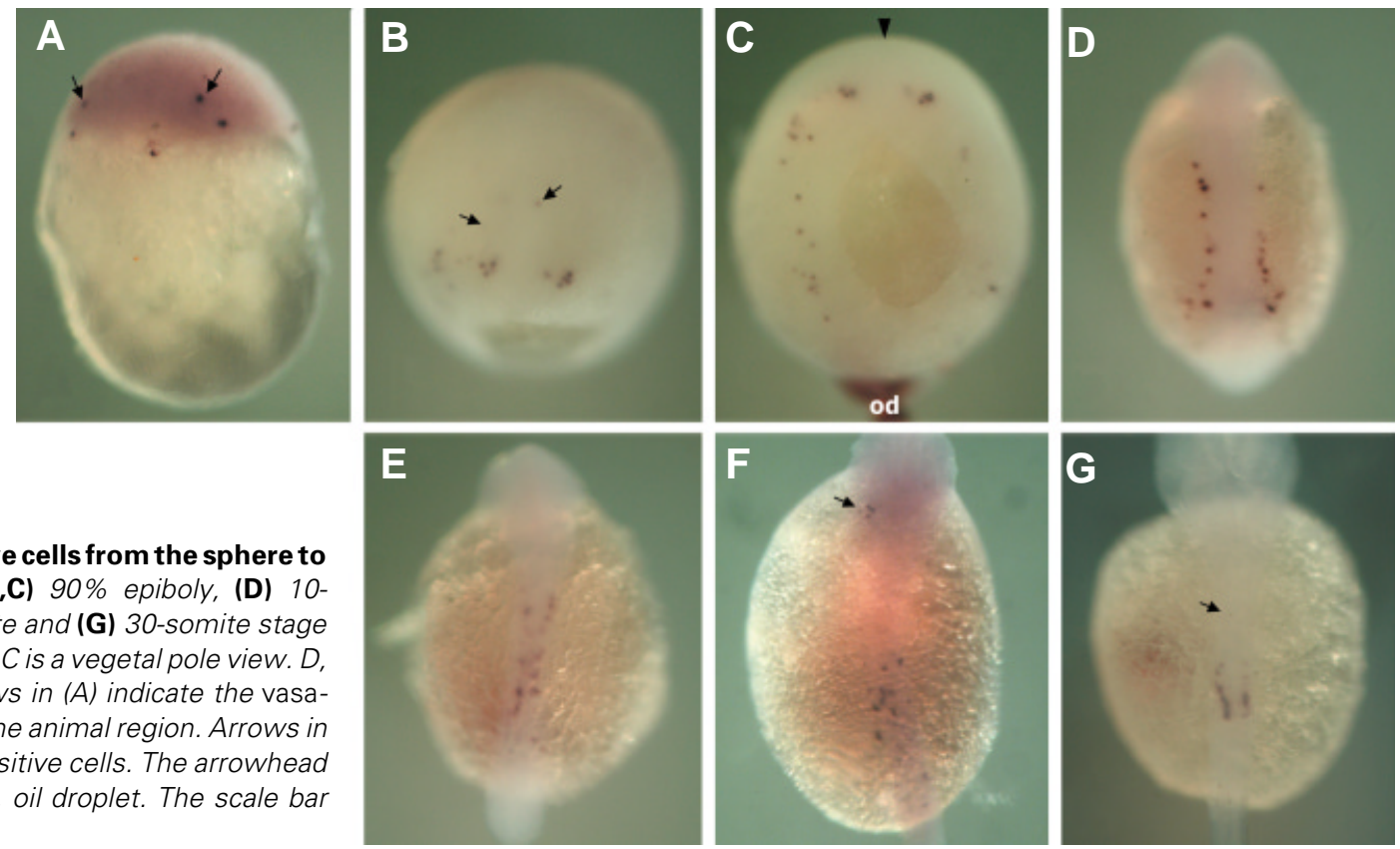

Fig. 2. Distribution of vasa-positive cells from the sphere to 30-somite stage. (A) Sphere, (B,C) $90 \%$ epiboly, (D) 10somite, (E) 15-somite, (F) 20-somite and (G) 30-somite stage embryos. $A$ and $B$ are lateral views. $C$ is a vegetal pole view. $D$, $E, F$ and $G$ are dorsal views. Arrows in $(A)$ indicate the vasapositive cells that were located at the animal region. Arrows in $B, F$ and $G$ indicate ectopic vasa-positive cells. The arrowhead in (C) indicates dorsal position. od, oil droplet. The scale bar indicates $50 \mu \mathrm{m}$.

At the 10-somite stage, PGCs were located in the lateral to trunk region of the lateral plate mesoderm. In this stage, many $P G C$ s came in contact with the yolk syncytial layer (YSL) (Fig. $3 \mathrm{~A}, \mathrm{~B})$. At the 20-somite stage, PGCs were located at a more axial part of the mesendodermal layer than before (Fig. 3 C,D). At the 20-somite stage, some PGCs were located on the dorsal midline of the endoderm region, but not observed in the region after the gut cavity was formed. At the 30 -somite stage, the majority of PGCs were in contact with the lateral part of the gut (Fig. 3 E,F). In 4-dpf embryos, PGCs were more dorsally located in the lateral plate mesoderm lateral to the gut and separated from the YSL (Fig. 3 G,H). PGCs of this stage were in close contact with the gut. In 6-dpf embryos, the majority of PGCs were located on the dorsal part of the gut (Fig. 3 I,J). In

TABLE 1

THE NUMBER OF VASA SIGNALS OR VASA-POSITIVE CELLS OBSERVED BY WISH FROM THE 16-CELL TO 90\% EPOBOLY STAGE

newly formed gut of the 4th- to 8th-somite region, however, some vasa-positive cells remained at the head region (Fig. $2 \mathrm{G}$ ). These vasa-positive cells localized at the head region were detected until at least 5-dpf embryos.

\section{Observation of PGCs in HE-stained histological sections}

To identify the location of PGCs after the somitogenesis period and the migration of PGCs in the germ layer, we observed paraffin sections of ukigori embryos from the blastula to 12-dpf stages. When we observed the gonadal anlage of 8-dpf embryos, the cells located around the dorsal peritoneum and upper part of the body cavity were identified as PGCs by the characteristics as mentioned in Materials and Methods (Fig. 3 $\mathrm{K}, \mathrm{L}$ ). The PGCs could be traced back to the 10 -somite stage. At the previous stages, PGCs could not be distinguished from somatic cells because eosinophilic yolk granules preserved in somatic cells prevent differentiation of PGCs and somatic cells.

\begin{tabular}{llc} 
Stage & \multicolumn{1}{c}{ No. of vasa positive cells (dots) } & Average \\
\hline 16 -cell & $4,4,4,4,4,4,4,4,5,5,5,5,5,6,6,6,6,6,7,7,7,7,7,8,8,8,8,8$, & 5.8 \\
512 -cell & $4,5,5,5,5,5,6,6,6,7$ & \\
shpere & $4,4,4,7,7,7,8,8,8,8,8,9,9,10,10,10,11,11,12,12,13,15,16,20$ & 9.6 \\
$30 \%$ epiboly & $8,11,11,12,12,13,14,14,14,14,15,16,18,18,19,20,20,21,24$ & 15.1 \\
$90 \%$ epiboly & $21,22,23,25,33,34,38,41$ & 29.6 \\
\hline
\end{tabular}

TABLE 2

THE NUMBER OF CLUSTERS OF VASA-POSITIVE CELLS OBSERVED BY WISH AT THE SHIELD STAGE

\begin{tabular}{lccccc} 
Stage & $\begin{array}{c}\text { Total No. of } \\
\text { embryos }\end{array}$ & $\mathbf{3}$ & $\mathbf{4}$ & $\mathbf{5}$ & $\mathbf{6}$ \\
\cline { 3 - 6 } & 40 & $1(2.5)$ & $16(40.0)$ & $16(40.0)$ & $7(17.5)$ \\
\hline $40 \%$ epiboly & 40 & & & & \\
\hline
\end{tabular}



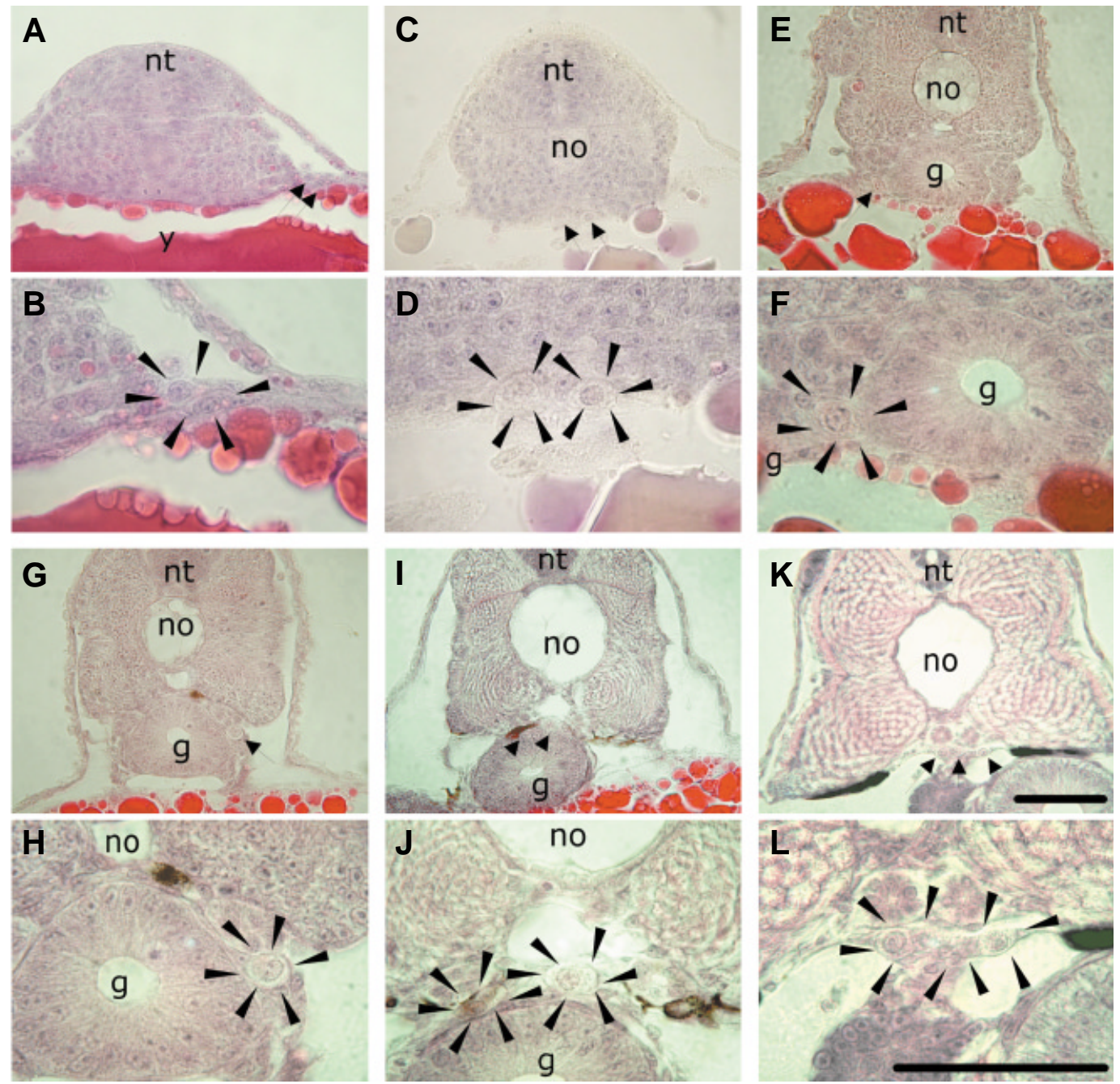

Fig. 3. Distribution of PGCs in transverse sections of ukigori embryos. (A,B) 10-somite, (C,D) 20-somite, (E,F) 30-somite, (G,H) 4 dpf, (I,J) 6 dpf and $(\mathbf{K}, \mathbf{L}) 8 \mathrm{dpf}$ stage embryos. $B, D, F, H, J$ and $L$ are higher magnifications of $A, C, E, G, I$ and $K$, respectively. Scale bars indicate $50 \mu m$.
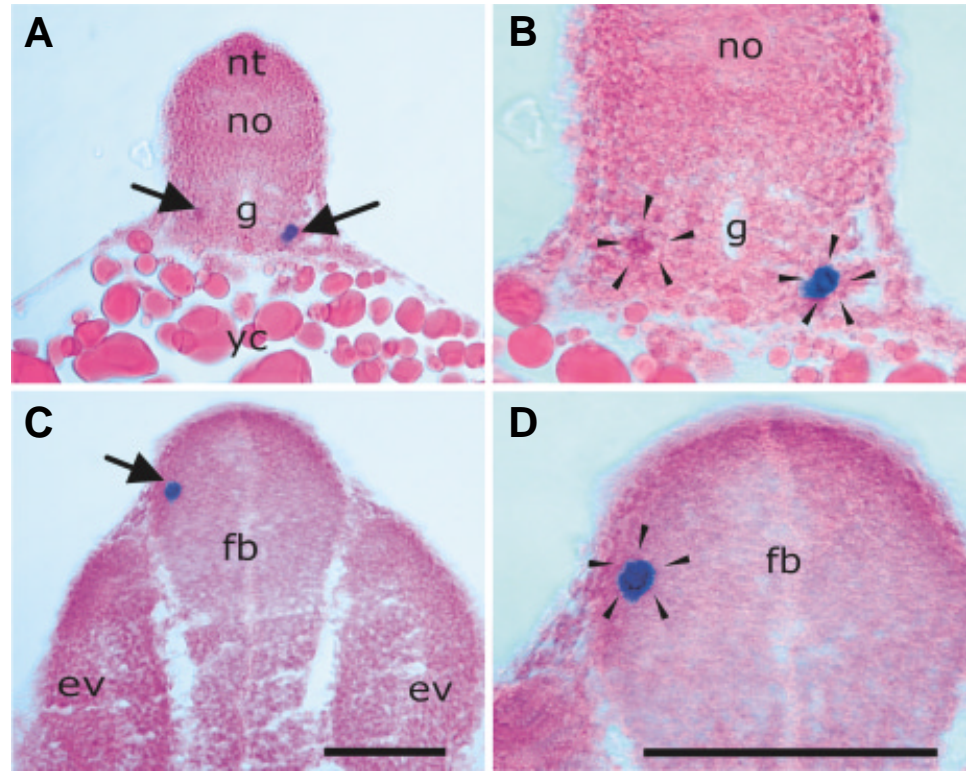

8-dpf embryos, most of them reached the dorsal peritoneum of the upper part of the body cavity (Fig. $3 \mathrm{~K}, \mathrm{~L}$ ).

\section{Comparison of vasa positive cells and histological PGCs}

To elucidate whether vasa positive cells were identical to histologically detected PGCs or not, WISH samples hybridized with vasa probes were sectioned and analyzed. In latesomitogenesis period embryos, vasa positive cells were observed mainly in the trunk region (Fig. 4 A,B) and sometimes in the head region (Fig. $4 \mathrm{C}, \mathrm{D}$ ). As a result, vasapositive cells were located at the same positions as PGCs observed histologically at the 20-somite stage (Fig. 2F). Moreover, the

Fig. 4. Light eosin-stained histological sections of WISH-stained embryos by vasa probe at the late-somitogenesis period. $(A, B)$ Transverse section images of the somite region. (C,D) Transverse section images of the head region. $B$ and $D$ are higher magnifications of $A$ and $C$, respectively. Arrows and arrowheads indicate vasapositive cells. ev, eye vesicle; fb, forebrain; g, gut; no, notochord; $n t$, neural tube; yc, yolk cell. Scale bars indicate $100 \mu \mathrm{m}$. 

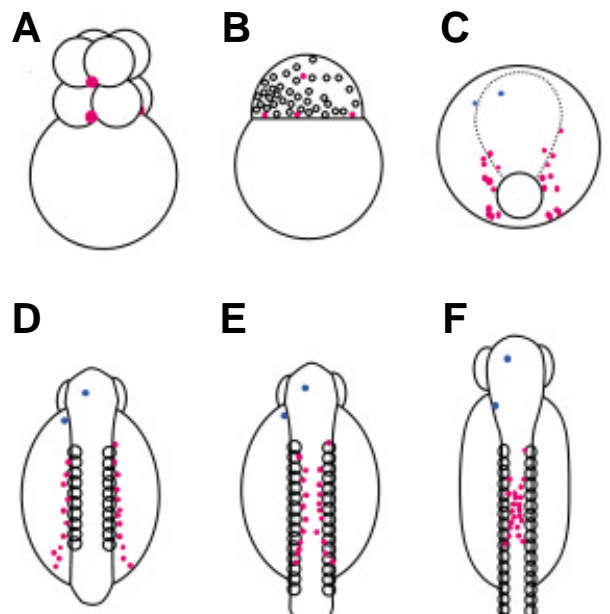

E
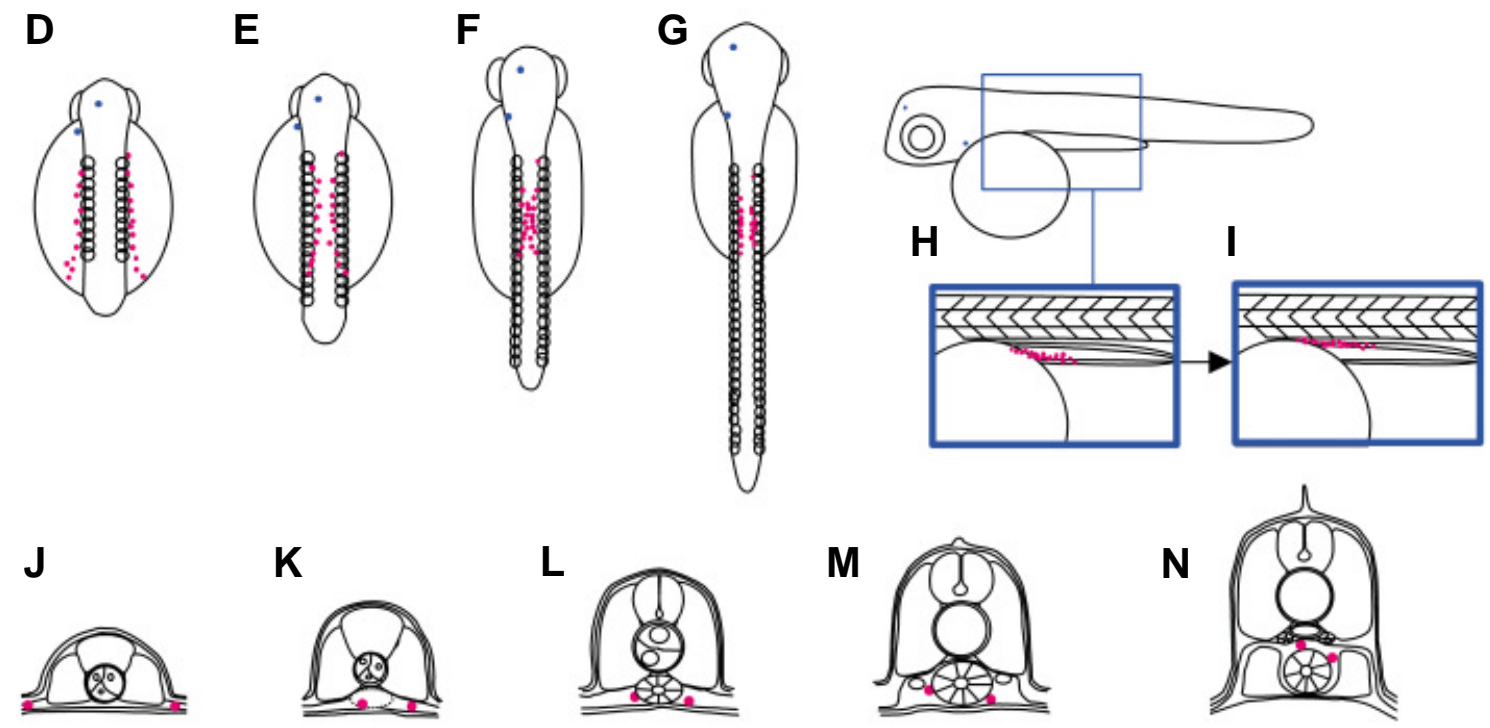

Fig. 5. A schematic illustration of PGC migration in Ukigori. (A-I) The origins and migration routes of PGCs. vasa transcripts localized at the cleavage furrows until third cleavage (A). vasa transcripts are taken into the single cells at the blastula stage (B). PGCs increase from the sphere stage and locate at the margin of the blastodisc (C). PGCs align at both sides of body axis from the bud to 10somite stage (D). PGCs locate under the body axis and gradually aggregate (E,F). PGCs align at both sides of the newly formed gut (G). PGCs migrate from the ventral side of the gut to the dorsal side, finally localizing in the genital ridge (H,I). (J-N) Transverse images of ukigori PGC migration. PGCs migrate toward the mid-line with close contact to the yolk syncytial layer (YSL) during the 10-and 30-somite stages (J-L). Thereafter, PGCs migrate to the genital ridge via the lateral plate mesoderm in close contact to the gut (L-N). The developmental stages of $J, K, L, M$ and $N$ correspond to $D, F, G, H$ and $I$, respectively. Red circles indicate PGCs. Blue circles indicate PGCs located in the ectopic region. average number of vasa-positive cells in WISH embryos was approximately equal to those of PGCs in HE-stained histological sections, at 10-somite stage (Table. 3 ).

\section{Discussion}

In this study, we carried out WISH by using shiro-uo vasa probes in ukigori embryos. vasa mRNA accumulated at the cleavage furrows and thereafter, signals were continuously observed in the restricted cells. The locations of vasamRNA were similar to those observed in other fish species in which the origin and dynamics of PGCs were reported by vasamRNA (Yoon et al., 1997; Otani et al., 2002). When post-WISH embryos at the 20somite stage were sectioned and observed, the location of vasa positive cells was consistent with PGCs observed at the same stage histologically. Moreover, the average number of vasa positive cells in WISH embryos was approximately equal to those of PGCs in HE-stained histological sections, at 10-somite stage. Thus, we concluded that the vasa positive cells were PGCs. Furthermore, shiro-uo vasa probe have been shown to detect ukigori PGCs.

The number of vasa signals varied (from 4 to 8 ) among embryos at the 16 -cell stage. At the $40 \%$ epiboly stage, the number of PGC clusters observed was between 4 and 6 . This suggests that vasa-positive cells originating from the third cleavage plane can divide and proliferate after the late blastula stage. In zebrafish, vasa signals from the third cleavage furrows did not proliferate (Yoon et al., 1997), but in goldfish, all signals from the third cleavage furrows proliferated (Otaninet al., 2002). This suggests that germ cells are determined by the amount of germinal factors and formation of PGCs are not restricted to specific edges of cleavage furrows. In the ukigori embryos, irregular dividing patterns were sometimes observed at the 8-cell stage (Saito et al., 2004). This irregular cleavage pattern may cause a distorted aggregation pattern of vasa mRNA and result in unstable numbers.

In ukigori embryos, vasa mRNA aggregated at both edges of the first, second and third cleavage furrows. Knaut et al. (2002) discussed that the mechanisms of aggregation of vasamRNA at the cleavage plane are lost in the Euteleostei including medaka and trout, different from the Osteriophysans. However, in this study, vasa mRNA aggregated at the edges of the cleavage furrows of ukigori embryos, which belong to the Euteleostei, at the cleavage period. Hence, there is room for reconsideration in terms of the relationship between the phylogenetic position of fish and the accumulation patterns of vasa transcripts.

PGCs were observed at the head region during the somitogenesis period in high frequency (50\%). Moreover, some head PGCs were histologically detected in the head ectoderm. In teleosts,

\section{TABLE 3}

THE NUMBER OF VASA-POSITIVE CELLS AND PGCS IN WISH AND HE-STAINED HISTOLOGICAL SECTIONS

\begin{tabular}{lcccc} 
Samples & Stage & $\begin{array}{c}\text { Embryos } \\
\text { analyzed }\end{array}$ & The number of PGCs in respective embryos & Average \\
\hline WISH & 10 -somite & 11 & $15,17,18,18,24,25,25,27,35,35,41$ & 25.5
\end{tabular}

HE-stained

histological 10 -somite $12 \quad 18,19,22,22,22,23,23,25,27,31,33,34 \quad 24.9$ sections 
PGCs have been observed in the trunk mesendoderm region during embryogenesis, but seldom around the head region, especially the head ectoderm. In goldfish, ectopic PGCs have been histologically detected around the head mesoderm and frequently in the head region (Kazama-Wakabayashi et al., 1999; Otani et al., 2002). These ectopic PGCs suggest that large scale mixing of blastomeres during the blastula stage carry some PGCs from the marginal zone to the animal pole region and consequently, that convergence movements produce ectopic head PGCs at the somitogenesis period (Otani et al., 2002). In ukigori embryos, vasa mRNA aggregations are occasionally formed at the middle part of the blastodisc, by the third horizontal cleavage plane (present study) and large scale mixing of blastomeres is also observed from the blastula to the epiboly stage (Saito et al., 2004), suggesting localization of PGCs around the prospective head region of the blastoderm during gastrulation, as in goldfish. However, the actual movement of PGCs to the head region is still unknown. Examination of the route of visualized PGCs during gastrulation, as in zebrafish, is required (Köprunner et al., 2001). The migration route, shown by histological sections and WISH in vasamRNA, of PGCs in ukigori is summarized in Fig. 5. Germ plasm aggregating in early cleavage furrows is inherited by several blastomeres during the blastula stage, the resultant founder cells of PGCs proliferate during epiboly and PGCs are located at both sides of the body axis during the subsequent segmentation period. These processes of PGCs movement are similar to those of other teleost fish species reported. Thereafter, however, PGCs in ukigori immediately migrate in the dorsal direction to the body axis during the subsequent segmentation period, instead of in the posterior direction as reported in other species. In the center of the body axis, PGCs from both sides seem to be mingled on the endoderm and redistributed to both sides of the gut. This PGC migration pattern is similar to that of the shiro-uo, belonging to the same family gobiidae as the ukigori (Saito et al., 2002). The timing of $P G C$ redistribution after 20 -somite stage is corresponded to the definite gut formation. It seems probable that the newly formed gut affecting the PGCs migration. On the other hand, in other species of fishes, such as zebrafish, goldfish and medaka, PGCs at both sides migrate posterior-ward to the presumptive genital ridge region, then localize in sides of gut in the course of the posterior movement (Weidinger et al., 1999; Shinomiya et al., 2000; Tanaka et al., 2001; Otani et al., 2002). In zebrafish, it has been reported that migration of PGCs is guided by the chemokine signal SDF-1a (Doitsidou et al., 2002). Therefore, the expression patterns of guidance signals such as SDF-1a remain to be examined. In final step of $P G C$ migration to the genital ridge, ukigori PGCs migrate along the inner layer of the lateral plate mesoderm lateral to the gut. This route of PGC migration has been observed in Fundulus heteroclitus(Richards and Thompson, 1921) and black bass (Johnston, 1951). In this step, PGCs migrate actively with pseudopodia to the genital ridge in zebrafish (Braat et al., 1999). On the other hand, in medaka embryos, PGCs move to the outer layer of the lateral plate mesoderm and migrate passively dorsal-ward, from light- and electron-microscopic observations (Gamo, 1961; Hamaguchi, 1985). From this point, PGCs seem to adopt several mechanisms in the final step to the genital ridge, although it is unclear whether PGCs in ukigori migrate to genital ridge passively or actively. Since there is little knowledge of the migration of $P G C$ s to the genital ridge, it is necessary to investigate the mechanism of migration of the later step to the genital ridge.
In summary, we identified the migration route of PGCs from the origin to the genital ridge during embryonic development in ukigori, Perciformes gobiidae. These results suggest that the migration routes and localized patterns of PGCs are influenced by embryonic development in each fish, although are mainly conserved. Further research on the migration of PGCs in ukigori would clarify the behavior of fish PGCs.

\section{Materials and Methods}

\section{Gametes and embryo culture}

Fertilized eggs of ukigori were sampled at the Moheji and Ryukei rivers, near Hakodate, in the southern part of Hokkaido, Japan, from April to June. Stones, on which eggs were spawned, were collected in the rivers and transferred to the Nanae Fresh-Water Laboratory. Eggs were removed from the stones and dechorionated by fine forceps. Dechorionated embryos were cultivated in Ringer's solution $(120 \mathrm{mM} \mathrm{NaCl}, 2.8 \mathrm{mM} \mathrm{KCl}$, $1.8 \mathrm{mM} \mathrm{CaCl}_{2}$ ) containing $0.01 \%$ penicillin-streptomycin and $1.6 \%$ egg albumen at $20^{\circ} \mathrm{C}$ until the epiboly period. After the epiboly or segmentation period, the embryos were cultivated in culture medium $\left(1.8 \mathrm{mM} \mathrm{CaCl}_{2}\right.$ and $1.8 \mathrm{mM} \mathrm{MgCl}_{2}$ ) containing $0.01 \%$ penicillin-streptomycin at $20^{\circ} \mathrm{C}$ until the hatching period. The developmental stages were determined by external morphology according to Saito et al., (2004).

\section{Whole mount in situ hybridization using vasa probe}

Whole mount in situ hybridization (WISH) was carried out essentially as described by Thisse et al. (1994) with slight modification. Antisense vasa probe from shiro-uo, Leucopsarion petersii, (Accession No. AB098252) containing $0.38 \mathrm{~Kb} D E A D$-box regions were prepared using a digoxigenin (DIG) RNA labeling kit (Roche). Manually dechorionated embryos were fixed with $4 \%$ paraformaldehyde in PBS for 20- to $30 \mathrm{~h}$. Fixed embryos were stored in $100 \%$ methanol at $-20^{\circ} \mathrm{C}$. Then embryos were rehydrated in PBT (1X PBS $0.1 \%$ Tween 20) 2 times for 5 min each. Embryos older than the beginning of somitogenesis were treated 10 to 60 min with proteinase $\mathrm{K}(10 \mu \mathrm{g} / \mathrm{ml}$ in PBT). Embryos were postfixed in $4 \%$ paraformaldehyde in PBS for 20 min and then rinsed in PBT 3 times for 5 min each. The embryos were prehybridized 3 hour at $62^{\circ} \mathrm{C}$ in hybridization buffer ( $50 \%$ formamide, 5 X SSC, $50 \mu \mathrm{g} / \mathrm{ml}$ heparin, $500 \mu \mathrm{g} / \mathrm{ml}$ tRNA, $0.1 \%$ Tween 20). The hybridization was done in the same buffer containing probe overnight at $62^{\circ} \mathrm{C}$. Then the embryos were washed at $62^{\circ} \mathrm{C}$ for 10 min in (50\% formamide, $50 \% 5$ X SSC, $0.1 \%$ Tween 20$), 10 \mathrm{~min}$ in $(50 \%$ formamide, $50 \% 2 \mathrm{XSSC}, 0.1 \%$ Tween 20 ), $10 \mathrm{~min}$ in (25\% formamide, $75 \%$ 2X SSC, $0.1 \%$ Tween 20), $10 \mathrm{~min}$ in (2X SSC, $0.1 \%$ Tween 20), 4 times $15 \mathrm{~min}$ in (0.2X SSC, $0.1 \%$ Tween 20). Further washes were performed at room temperatures for $5 \mathrm{~min}$ in PBT and then 1 8 hour in Blocking solution (PBT with $10 \%$ blocking reagent). Then the embryos were incubate overnight at $4{ }^{\circ} \mathrm{C}$ with anti-digoxigenin antiserum (Roche) at a 1/8000 dilution in a blocking solution and then embryos were washed 6 times for 20 min each in PBT at room temperature. Then embryos were washed 3 times for 5 min each in Staining buffer $(100 \mathrm{mM}$ Tris $\mathrm{HCl} \mathrm{pH} \mathrm{9.5,}$ $50 \mathrm{mM} \mathrm{MgCl}, 100 \mathrm{mM} \mathrm{NaCl}, 0.1 \%$ Tween 20). Detection was performed in Staining solution ( $3.375 \mathrm{mg} / \mathrm{ml} \mathrm{NBT}, 1.75 \mathrm{mg} / \mathrm{ml} \mathrm{BCIP}$, Staining buffer) at $4^{\circ} \mathrm{C}$. When the color was developed, the reaction was stopped in $1 \mathrm{X}$ PBS. Photographs were taken using an Olympus CAMEDIA imaging system DS3030U equipped with a SZX-12 stereomicroscope.

\section{Histology}

For histological observation, embryos were fixed with Bouin's fixative for $2 \mathrm{~h}$, dehydrated in a butyl alcohol series and embedded in paraffin. Serial sections were cut $8 \mu \mathrm{m}$ thick. PGCs were confirmed based on location and characteristics; such as round shape, large nuclei, relatively large size and clear nuclear membrane, similar to those observed in other fishes (Braat et al., 1999; Kazama-Wakabayashi et al., 1999; Nagai et al., 2001). The PGCs size varied between 10 and $20 \mu \mathrm{m}$. Using these 
characteristics, the origin of the PGCs could be traced back to the 10somite stage.

WISH samples stained with vasa probes were dehydrated in a butyl alcohol series and embedded in paraffin. Serial sections were cut $12 \mu \mathrm{m}$ thick. The location of vasa positive cells was compared with HE-stained PGCs.

\section{Acknowledgements}

We thank Mr. Shizuo Kimura, Ms. Chikako Nishida and the members of Nanae Fresh Water Laboratory (Field Science Center for Northern Biosphere, Hokkaido University. This study was supported by the Research Fellowships of the Japan Society for the Promotion of Science (JSPS) for Young Scientists, to T. Saito (No. 0446), a Grant-in Aid for Scientific Research (B) from JSPS to E.Y (No. 16380124) and COEprogram to Graduate School of Fisheries Science, Hokkaido University.

\section{References}

BRAAT, A.K., ZANDBERGEN, T., VAN DE WATER, S., GOOS H.J. and ZIVKOVIC, D. (1999) Characterization of zebrafish primordial germ cells: morphology and early distribution of vasa RNA. Dev. Dyn. 216: 153-167.

DOITSIDOU, M., REICHIMAN-FRIED, M., STEBLER, J., KÖPRUNNER, M., DORRIES, J., MEYER, D., ESGUERRA, C.V., LEUNG, T. and RAZ, E. (2002) Guidance of primordial germ cell migration by the chemokine SDF-1. Cel/111: 647-659.

GAMO, H. (1961) On the origin of germ cells and formation of gonad primordia in the medaka, Oryzias latipes. Japan J. Zool. 13: 101-115.

HAMAGUCHI, S. (1982) A light- and electron-microscopic study on the migration of primordial germ cells in the teleost, Oryzias latipes. Cell Tissue Res. 227: 139151.

HAY, B., JAN, L.Y. and JAN, Y.N. (1988) A protein component of Drosophila polar granules is encoded by vasa and has extensive sequence similarity to ATPdependent helicases. Cel/55: 577-587.

HOWARD, K. (1998) Organogenesis: Drosophilagoes gonadal. Curr. Biol. 8: R415417.

JOHNSTON, P.M. (1951) The embryonic histology of the germ cells of the largemouth black bass, Micropterus salmoides salmoides (Lacépède). J. Morphol. 88: 471-542.

KAZAMA-WAKABAYASHI, M., YAMAHA, E. and YAMAZAKI, F. (1999) The elimination and duplication of lower part of blastoderm effects on the number of primordial germ cells in goldfish. Fish. Sci. 65: 577-582.

KNAUT, H., STEINBEISSER, H., SCHWARZ, H. and NUSSLEIN-VOLHARD, C. (2002) An evolutionary conserved region in the vasa 3'UTR targets RNA translation to the germ cells in the zebrafish. Curr. Biol. 12: 454-466.

KOBAYASHI, S., YAMADA, M., ASAOKA, M. and KITAMURA, T. (1996) Essential role of the posterior morphogen nanos for germline development in Drosophila. Nature 380: 708-711.

KÖPRUNNER, M., THISSE, C., THISSE, B. and RAZ, E. (2001) A zebrafish nanosrelated gene is essential for the development of primordial germ cells. Genes Dev. 15: 2877-2885.

LASKO, P.F. and ASHBURNER, M. (1988) The product of the Drosophila gene vasa is very similar to eukaryotic initiation factor-4A. Nature 335: 611-617.
NAGAI, T., YAMAHA, E. and ARAI, K. (2001) Histological differentiation of primordial germ cells in zebrafish. Zool. Sci. 18; 215-223.

OTANI. S., MAEGAWA, S., INOUE, K., ARAI, K. and YAMAHA, E. (2002) The germ cell lineage identified by vas-mRNA during the embryogenesis in goldfish. Zool. Sci. 19:519-526

RAZ, E. (2002) Primordial germ cell development in zebrafish. Semin. Cell. Dev. Biol. 2002 13: 489-495.

RICHARDS, A. and THOMPSON, J.T. (1921) The migration of the primary sex-cells of Fundulus heteroclitus. Biol. Bull. 40: 325-349.

RONGO, C., BROIHIER, H.T., MOORE, L., VAN DOREN, M., FORBES, A. and LEHMANN, R. (1997) Germ plasm assembly and germ cell migration in Drosophila. Cold Spring Harb. Symp. Quant. Biol. 62: 1-11.

SAITO, T., OTANI, S., NAGAI, T., NAKATSUJI, T., Arai, K. and YAMAHA, E. (2002) Germ cell lineage from a single blastomere at 8-cell stage in shiro-uo (ice goby). Zool. Sci. 19:1027-1032.

SAITO, T. and YAMAHA, E. (2004) Aspects and prospective of surrogate propagation in teleost fish. J. Anim. Genet. 31: 47-55 (in Japanese).

SAITO, T., ARAI, K. and YAMAHA, E. (2004) The embryonic development of shimaukigori, Gymnogobius opperiens. Suisanzoshoku 52: 177-184 (in Japanese).

SCHÜPBACH, T. and WIESCHAUS, E. (1986) Germline autonomy of maternaleffect mutations altering the embryonic body pattern of Drosophila. Dev. Biol. 113: 443-448.

SHINOMIYA, A., TANAKA, M., KOBAYASHI, T., NAGAHAMA, Y. and HAMAGUCHI, S. (2000) The vasa-like gene, olvas, identifies the migration path of primordial germ cells during embryonic body formation stage in the medaka, Oryzias latipes. Dev. Growth. Differ. 42: 317-326.

TANAKA, M., KINOSHITA, M., KOBAYASHI, D. and NAGAHAMA, Y. (2001) Establishment of medaka (Oryzias latipes) transgenic lines with the expression of green fluorescent protein fluorescence exclusively in germ cells: A useful model to monitor germ cells in a live vertebrate. Proc. Natl. Acad. Sci. USA. 98: 2554-2549.

THISSE, C., THISSE, B., SCHILLING, T.F. and POSTLETHWAIT, J.H. (1993) Structure of the zebrafish snail 1 gene and its expression in wild-type, spadetail and no tailmutant embryos. Development 119: 1203-1215.

TSUNEKAWA, N., NAITO, M., SAKAI, Y., NISHIDA, T. and NOCE, T. (2000) Isolation of chicken vasahomolog gene and tracing the origin of primordial germ cells. Development 127: 2741-2750.

WEIDINGER, G., WOLKE, U., KÖPRUNNER, M., KLINGER, M. and RAZ, E. (1999) Identification of tissues and patterning events required for distinct steps in early migration of zebrafish primordial germ cells. Development 126: 5295-5307.

WYLIE, C. (1999) Germ cells. Cel/96; 165-174.

YOON, C., KAWAKAMI, K. and HOPKINS, N. (1997) Zebrafish vasa homologue RNA is localized to the cleavage planes of 2- and 4-cell-stage embryos and is expressed in the primordial germ cells. Development 124: 3157-3165.

YOSHIZAKI, G., TAKEUCHI, Y., KOBAYASHI, T. and TAKEUCHI, T. (2004) Primordial germ cells: A novel tool for fish bioengineering. Fish. Physiol. Biochem. (in press)

Received: June 2004

Reviewed by Referees: July 2004

Modified by Authors and Accepted for Publication: October 2004 Edited by: Makoto Asashima 